\title{
POWER IN PTOLEMAIC EGYPT: A MAGICAL-RELIGIOUS APPROACH TO LEGITIMACY
}

Julio Gralha ${ }^{1}$

\begin{abstract}
This paper aims to present strategies that allowed the Ptolemaic dynasty to establish its legitimacy for almost three centuries. In fact, I argue that a political-religious project that focused on the adoption of Egyptian magical-religious practices and the divine monarchy was carried out by Ptolemaic royalty. In this research I cite as an example four strategies: Ptolemaic legitimacy by means of deification, by means of foundation of a city, by means of royal titles and, by means of building of temples. I also argue that the development of a temple-building program in Upper Egypt, especially after the Theban Rebellion, was able to establish cooperation and co-optation of the elite and local social segments, consolidating dynastic legitimacy. Moreover, I argue that the Egyptianization of Ptolemaic royalty is deeper than historiography stands out compared to Hellenization.
\end{abstract}

Keywords

Ptolemaic dynasty, 305-30 B.C.; Egyptology; Ancient History; Power Relation.

\footnotetext{
${ }^{1}$ Assistant Professor, Fluminense Federal University, Campos, Brazil. Assis, Brasil. email: ierocha@uol.com.br
} 


\section{Resumo}

Este artigo tem por objetivo apresentar estratégias que permitiram a dinastia ptolomaica estabelecer sua legitimidade por quase três séculos. De fato, defendo que um projeto político-religioso, que tinha por foco a adoção de práticas mágico-religiosas egípcias e da monarquia divina foi levado a efeito pela realeza ptolomaica. Nesta pesquisa cito como exemplo quatro estratégias: A legitimidade ptolomaica pela deificação, pela fundação de cidade, pela titulação e pela construção de templos. Defendo também que o desenvolvimento de um programa de construção de templos no Alto Egito, principalmente após a Rebelião Tebana, foi capaz de estabelecer a cooperação e a cooptação da elite e segmentos sociais locais consolidando a legitimidade dinástica. Além disso, defendo que a egipcianização da realeza ptolomaica é mais profunda do que a historiografia ressalta se comparada a helenização.

\section{Palavras chave}

Dinastina Ptolomaica 305-30 b.C.; Egiptologia; História Antiga; relações de poder. 
Unlike some authors who argue little interaction between Egyptian and Greco-Macedonian cultures, the legitimacy of the Ptolemaic dynasty allows us to verify that such interaction was much deeper than we might think, and probably without such an approach it would be difficult to maintain this "foreign dynasty" for nearly three centuries. According to Gunther Holbl (2001) "the power structure of the Ptolemies did not have a strong feature in the first three Egyptian dynasties", however this does not mean the non-adoption of divine Egyptian monarchy and his magicreligious practices by Ptolemaic dynasty in this period.

A good example of this interaction was the practice of the Ptolemaic dynasty to perform marriages between brothers - a strange cultural element to the Greco-Macedonian. This practice was early adopted in the Ptolemaic dynasty during the reign of Ptolemy II Philadelphus and was described in the Mendes stele - decree on the city of Mendes in Lower Egypt

It is possible that revolts during the reign of Ptolemy IV and V may have favored significantly the adoption of Pharaonic divine monarchy. In any case, the legitimacy of the Ptolemaic dynasty should consider both cultures and a good example of this religious practice can be verified in the concern of Ptolemy I to establish Serapis as a deity.

According to Plutarch in his work "De Iside et Osiride" Ptolemy would have had a dream in which the statue of an unknown god appeared to the monarch. Reporting this fact to his advisers they discovered that statue existed in the Greek colony of Sinope and soon as possible it was brought to Egypt.

The narrative can be translated as divine revelation to the monarch and a form of legitimacy for social segments, since this deity should have elements of Egyptian and Greek culture. It is not clear if Serapis had great acceptance on Egypt, but his cult was significant in the Greco-Roman world.

According to the doctoral thesis of Professor Lobianco (2006: 237-239), citing the work of Françoise Dunand and Christiane Zivie-Coche (1991: 214-216), this god had become the object of worship before the arrival of Alexander and was known by the Greek population of Memphis in the form of Osor-Hapi. In fact, it would have connection with the mummified Apis bull.

It is also possible to verify in Serapis; Osiris, Apis (both Egyptian gods) and Zeus (Greek god) attributes. The iconography represented him 
similar to the Hellenized Zeus with Cerberus on the side. But what interests us at this moment is the strategy carried out by the Ptolemaic dynasty establishing an official cult for this god as one of the phases in the process of legitimacy of power contemplating both cultures - the Egyptian and Greek - on Egyptian land.

In this way, during the formation of the Ptolemaic dynasty, Serapis could be thought, at first, as an example of cultural hybridism (see Bhabha, 2003). We understand this cultural hybridism as a transculturation in zones of contact to support the process of affirmation of this new dynasty, above all in the Delta (Northern Egypt) and Fayum. Despite being a post-colonial theory it seems applicable in different stages of formation of the Ptolemaic dynasty, on the other hand the strong adoption of the divine Pharaonic monarchy (after Ptolmy III) in the maintenance of power does not seem to satisfy this concept.

The idea to establish a hybrid god (Serapis in this case) was necessary for the process legitimacy of the Ptolemaic dynasty. The purpose was to contemplate separately both culture in just "one god" - Egyptian and the Greco-Macedonian. Thus, the ptolomaic monarchs were associated to Egyptian pantheon, to the magic-religious practices and priestly groups, especially the school priest of god Ptah of Memphis and on the other hands they established a connection, a lineage from Alexander of Macedonia.

In his passage through Egypt, Alexander traveled several days to consult the oracle of the Siwa Oasis dedicated to Zeus-Amon and the latter, by his faith, confirmed him as divine heir of Egypt. Probably this legitimacy was based on a legend (Hobl, 2001: 78) whose narrative puts Alexander as the son of Olympia and Nectanebo II 2 - the last native pharaoh before the second Persian invasion.

The reason of Alexander did not consult the oracle of Thebes - dedicated to the Egyptian god Amon-Ra - can be evidence that this oracle was not able to give legitimacy to this conqueror in both cultures - GreekMacedonian and Egyptian culture.

\section{The Ptolemaic legitimacy by deification}

Among the magical-religious mechanisms to contribute to the legitimacy of the divine monarch is possible to cite the deification either in life or

\footnotetext{
${ }^{2}$ Nectanebo II reigned from 359-342 BC and was defeated by Persians
} 
after death. The deification of life was rare in pharaonic Egypt and can be verified in the reign of four monarchs who developed this practice, apparently as part of a political-religious project - Hatshepsut (the queen-pharaoh), Amenhetep III, Akhenaten and Ramses II .

Ramses II can be considered a good example of deification. He was the third pharaoh of the 19th dynasty3, who reigned from 1290 to1224 BC and was the last monarch to establish this process almost seven centuries before Ptolemy I. Apparently the project undertaken during his reign seems to have been the most viable, sustainable and effective.

Ramses II seems to have oriented his political-religious project to establish definitively the legitimacy of the new dynasty since it did not have significant family ties with the 18th dynasty. In this sense, he instituted the capital in the Delta, in the city of Pi-Ramsés that at the moment was the center of the Empire. He prioritized the main priestly schools (Memphis, Heliopolis, Hermopolis, Thebes and Elefantine), but seems to have emphasized the cult of Ra of Heliopolis.

His power was so significant that he appointed as high priest of god Amun-Ra at Thebes one priest of god Ptah of Memphis (Kitchen, 1982: 175) reducing and keeping under his control the power of city of Thebes. We defend the possibility that Ramses II have developed this practice based on Hatshepsut, Amonhotep III and Akhenaten reigns, as continuity of the political-religious project that would lead to legitimate himself as a living god. Professor Kitchen argues that this monarch took as an example the one hand Amonhotep III, pharaoh who established a period of wealth, peace, development, and became a god with the right to divine worship in life. On the other, Akhenaten, taking care not to proceed like this god-king (Kitchen, 1982: 175).

The reason to defend the possibility that the Queen / Pharaoh Hatshepsut has been taken into account, lies in the fact that she was "the first monarch" known in the New Kingdom that has developed a kind of worship (to her image in life) for herself establishing her legitimacy through myths of divine conception and birth.4 Similarly Amenhetep III was inspired by her adoption of myths5 and established the worship for himself in life.

\footnotetext{
3 From studies carried out during the master's degree. See (Gralha, 2002). The revised edition was published in 2017.

${ }^{4}$ See full analysis in chapter IV (Gralha, 2002) and (Gralha, 2017).

5 This myths can be found in Luxor Temple.
} 
She merged (as divine assimilation) to the god Amun-Ra in her (Hatshepsut) iconography, and something similar was done by Ramses II in relation to the gods Ra, Amun-Ra and Harakhty. Ramses II seems to have restored and used the temple of Hatshepsut, while dismantled what still remains of Akhet-Aten or Amarna - the capital city built by Akhenaton during his reign. Ramses II was the monarch who used more efficiently the architecture, iconography and texts to establish their legitimacy and dynastic divine.

But how this might work in the case of the Ptolemaic dynasty during the Hellenized period? This practice was implemented easily? There was some kind of cultural resistance on the magical-religious practices?

Apparently, does not seem to have existed significant resistance to the adoption of Egyptian magical-religious practices, and if so, the evidence is weak. During the reign of Ptolemy I, the construction of the Museion (Museum)6 and the Library of Alexandria gave to the Ptolemies prestige in face of Greek culture and contributed to the legitimacy of royal power. What is interesting about this type of "Museum" is the practice of a cult (worship).

The Museum is, in its origin, a sacred place where a cult was held to the divine muses who presided over the memory and activities of the spirit (Husson and Valbelle, 1992: 195).

The worship of the individual in the fifth and fourth century BC was no stranger to the Greek world, especially for the founders of cities. According to G. Husson and Dominique Valbele the explication for the Hellenistic royal cult is based on an oriental influence, in particular the Achaemenid royality (Persia) and the cult of the Greek cities dedicated to his men, dead or alive, but not consider them gods. To this kind of cult the Egyptologist named as the royal worship(cult) of the Greek type. 7 On the other hand, the same worship (cult) has similar elements to the worship (cult) of the Egyptian monarch, whether in the form of worship in life, whether in the form of the memorial service to the pharaoh, which occurred in temples executed by a specific group of priests. In this sense, Ramses II, for example, was the object of such worship in the temple of Abu Simbel in southern border of Egypt, Ramses III, in turn, at Medinet Habu on the left bank of the Nile (the opposite side of the capital Thebes)

\footnotetext{
6 This kind of museum has no current relationship with the actual museum according to the researchers

${ }^{7}$ Le culte royal de type grec.
} 
From the reign of Ptolemy II (284-246 BC) the divine expression of the monarch seems to have reached a new level. Soon after the death of Ptolemy I, the new ruler Ptolemy II created a cult in honor of his dead father which Husson and Valbelle (1992: 196) denominated as a filial cult. When the queen Berenice I died, his mother, she was also associated with the cult as a divine couple treated as savior gods (Theoi Soteres) and it seems to have evidence of a temple in Alexandria dedicated to the worship of Berenice around 275 BC (Holbl, 2001: 94).

This cult (worship) has close relationship with the pharaoh's memorial service, specially common in the New Kingdom (1550-1070 BC). Given the importance of worship, Ptolemy II established the Ptolemaia in Alexandria as a grand festival in honor of his father. Husson and Valbele (1992: 196) argue:

... he (Ptolemy II) had founded these parties (Ptolemaia and procession of Dionysus) in honor of his father, his organization shows clearly that they were designed to consolidate the prestige of the dynasty (Ptolemaic) in face of the Greeks because it was an agon isolympios that competed equally with the Olympics games.

This cult during the reign of Ptolemy II was so significant that it intended to compete with other festivals in Greek world and it is interesting to note that Egyptian magical-religious practices were present. If Ptolemy I attempted to strengthen dynastic legitimacy with the cult of Serapis, the practices promoted by Ptolemy II gave continuity to the political-religious project. The quote below concerning research on the worship of the pharaoh's memory may elucidate the function of magical-religious practices.

Recently, became common the use of the concept memorial temple which could be translated as temple dedicated to the memory of the monarch, since, "feed" the monarch would not be the only action. Apparently, there was a ritual to keep alive the memory of the king, because the monarch was a god. Thus the temple, besides having funeral rites and ritual in memory of the monarch was also the site of worship to the gods (Gralha, 2002).

Moreover, Ptolemy II also established a kind of cult in the form of the dynastic royal couple named Theoi Adelphoi (Gods brother-sister) even before the death of Arsinoe II, and evidences can be found on papyrus Hibeh 199 (272/1 BC).

In this type of practice the divine couple was the object of divine worship in life, i.e. living gods. To a certain extent such practice had relations with the dynastic cult to the pharaoh during the pharaonic period that only at certain moments had the cult status in life as gods (not memory worship). 
In this way the cult of the filial type and the dynastic type could be significant in establishing magical-religious and dynastic legitimacy, especially in the Delta and Fayum, on the other hand it was not enough in Upper Egypt to establish a kind of dynastic control. The expression of materiality was not satisfactory for that region. For a comprehensive study of the reign of Ptolemy II and the worship/cult of Arsinoe II I suggest the master degree thesis O Culto a Arsinoe II Filadelfo (The Cult of Arsinoe II Philadelphus) defended by Professor Alex Almeida dos Santos in 2003 at the Museu de Arqueologia e Etnologia da USP (Museum of Archaeology and Ethnology of the USP).

The Ptolomaic legitimacy by means of the founding of the city

The foundation of a city is another possible way of establishing legitimacy. In this case, the city may became the capital of the kingdom and (or) the house of the dynasty. Several pharaohs founded cities in the process of legitimacy of power. Akhenaten, for example, in his politicalreligious project founded the city of Akhet-Aton (Horizon of Aton) located between Thebes and Heliópolis, and now known as Amarna. Establishing the new capital changed the axis of power from Thebes, due to the cult of Amon-Ra, to Akhetaton, due to the worship of the god Aton, worship of exclusively solar character and apparently also associated to city of Heliopolis.8

Ramses II, during his reign, founded the city of Pi-Ramses (house of Ramses) it seems in order to strengthen the solar worship in Lower Egypt (north), but also as a way of being in the center of the Empire, what means to be between Nubia (Sudan) in southern and regions near the Orontes River (Lebanon-Syria).

In view of these examples, it would be important for the Ptolemaic dynasty to found a city because of the great impact that such a practice would have on the process of legitimacy of power relations. As Alexandria and Naukratis - the latter founded during the 26th Egyptian dynasty (7th century BCE) with Greek population for the most part were consolidated as Hellenized cities a new city in Lower Egypt (in the Delta) might not have had as much impact. The Delta was relatively smaller, cosmopolitan, and there was probably an easier way to get from one city to another. Upper Egypt would surely be the big problem for the Ptolemaic administration because it is less cosmopolitan, less population

8 See Gralha ( 2002) chapter IV. 
density, and far from the center of power. From the socio-cultural point of view, it is possible that hellenization 9 and egypciniazation 10 were more evident in the Delta.

Thus the foundation of the city of Ptolemais by Ptolemy I -considered a Greek city - in Upper Egypt was part of the process of legitimacy of power in southern Egypt and would be the expression of public material intended by this monarch. However, the Hellenistic characteristic of this city if on the one hand favored the Greek-Macedonian segments, on the other hand may not have been satisfactory before the pharaonic culture, and in that sense, did not establish strong ties with the tradition of Pharaonic Egypt that saw in Thebes its major city in the region. That is, during this period the divine monarchy (the Pharaonic type or model) was not yet consolidated by the Ptolemaic kings, and therefore, divine legitimacy seemed to express itself in an unsatisfactory way in regard to the founding of cities, especially in Upper Egypt.

\section{The Ptolemaic legitimacy by means of building Temples}

A temple-building program seems to be the best expression of materiality and Ptolemaic dynastic legitimacy because of its symbolic, mythic and magical-religious value, as well as promoting social relations, cultural relations (in a way like cities) and consolidating relations of power.

Thus, the founding of significant temples in the South, from the end of Ptolemy III's reign, may have been a significant aspect of the expression of materiality and public transcription in the process of dynastic legitimacy; and in turn reduced the resistance to the Ptolemaic dynasty, which had occurred in the form of revolts such as the Theban Rebellion (206-186 BC) that divided the "Two Lands" - Upper and Lower Egypt once again.

Due to the revolts (or not) and the changes in the cult of the monarch in the reigns of Ptolemy IV and V - mainly from 206 BC - we argue that it is possible that a deep process of Egyptianization was carried out having as a significant element the adoption of the a divine monarchy whose expression of materiality would be translated into a program of building temples and additions in the region of Upper Egypt, especially during the reigns of Ptolemy IV to VIII due to the complex relations before the Ptolemaic dynasty.

\footnotetext{
9 The adoption of Greek culture.

10 The adoption of Egyptian culture.
} 
What interests us is precisely to identify one of the forms found by the Ptolemaic dynasty, from Ptolemy IV, to establish social and political control, especially after the Theban Rebellion in order to reinforce the legitimacy of Ptolemaic power in Upper Egypt. Probably troops were sent to this region and administrative centers were organized mainly in the city of Ptolemais, but this alone might not be enough to establish control in this region. A divine legitimacy similar to that held by the Pharaohs would be necessary as a non-coercive means of control. In this way, it was necessary to use magical-religious practices that had already been put into practice by the Ptolemaic dynasty since Ptolemy I and the materialization of this legitimacy would be a program of temple constructions in important regions of Upper Egypt.

Apparently the first three monarchs did not include large temples in the construction program in this region. However, in the reign of Ptolemy III an effort in this direction was realized perhaps realizing the fragility of social control in the South. Thus, in $237 \mathrm{BC}$ began the construction of a significant temple - Horus temple in Edfu -, partly continued by Ptolemy IV. Nevertheless, the revolt was imminent and during such period the works were paralyzed.

From Ptolemy IV to Ptolemy VIII this building program led to the realization of works or additions to the most important temples of the region that took tens of years to be completed. The most important temples are: the temple of Hathor in Dendera, to the temple of Horus in Edfu, to the temple of Knum in Esna, to the temple of Horus and Sobek in Kom Ombo, to the temple of Isis in Philae and to the temple of Horus in Kalabsha (near Elefantina) having as Pharaoh Augustus. This last one erected in the transition between the Ptolemaic dynasty and the Roman occupation.

\section{The Ptolemaic Legitimacy by means of Pharaonic titles}

It seems appropriate to use the work developed on the dissertation about Pharaonic titles 11 in order to demonstrate the legitimacy of the Ptolemaic titles since the name or denomination was of great importance in the materiality of magical-religious processes. Thus, we take the definition of magic and magical action developed by Richard Wilkinson (1994) which demonstrates that in the Egyptian belief, describe or write a given situation, in a ritual process, such action could become real. It means that

${ }^{11}$ Defended in 2000 e published in2002. 
titles and epithets carried a magical-religious significance that could be applied to the human world.

In this sense the creation of a titles and epithets for the pharaoh could show the divine characteristics and attributes of the future monarch, his "government program", reaffirmed the king's dual nature (human and divine) and their relationship to the gods. The title then goes on to provide a set of words that had power and by magical practices could express the materiality of the actions of the pharaoh - sometimes as a human being, sometimes as divine being - making mention of the of the nature dual aspects of the king.

In the study of the king's two bodies (the dual nature of the monarch), developed by Egyptologist Siegfried Morenz (1996:37) the epithets hem and niswt can be taken as an example. About the epithet hem translated in documents as "your majesty" - Siegfried argues to be originally the word "body" (and others Egyptologists define as "servant") would be linked to human nature of the person holding the real function. According to Silverman (1991: 67) is related to the living embodiment of the king, or the person of Pharaoh, and it was the way in which the king was described by others (like biographies) or by himself. As for the term niswt (another form of defining "king") represent the functions and attributes of the monarch in a divine sense.

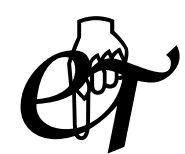

$\mathrm{hm}$

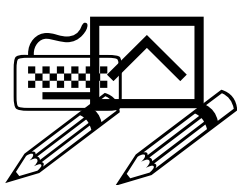

nsw bity

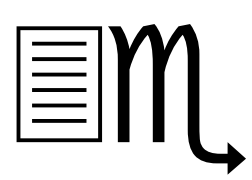

ntr nfr

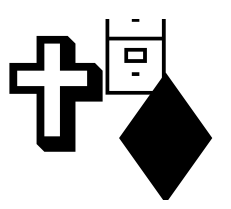

wa-n-ra

Fig. 1. Epithets and elements of King's titles.

The monarch's official names consisted of five royal titles, especially from the Middle Kingdom (2040 - 1640 BC). Most of these five titles seems to have been developed during the Old Kingdom (2575-2134 BC) and the First Intermediate Period (2134-2040 BC).

Regarding the epithets, they were found in all periods and varied depending on the moment. We describe the five titles that made up the king basic titles based on the definitions proposed by Egyptology (Boheme, BIFAO 78, 1978: 347; Boheme and Forgeau, 1988: 36-40, Allen, 2004: 64-65). 

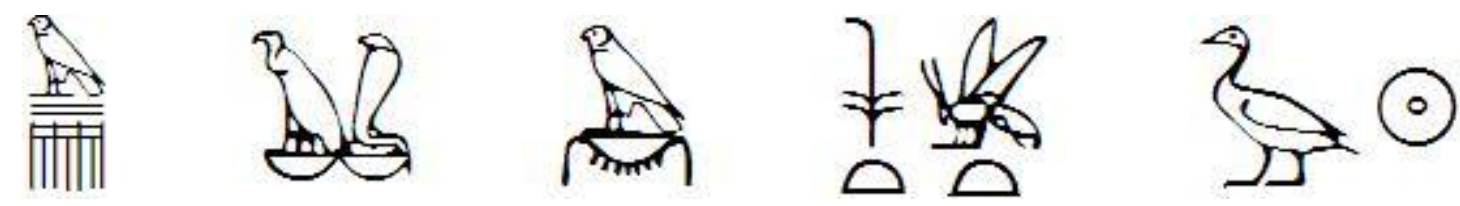

Fig. 2. Titles of the king.

HORUS - This title may be found in the first monarchs of the Archaic Period (2920-2575 BC). The name of the pharaoh was a rectangle inscribed, in fact represented a large room with columns that could be the palace of the monarch. As Pharaoh was identified with the god Horus his was drawn on the room or rectangle showing the protection and supremacy of this deity (this is not the Horus son of Isis and Osiris, but Horus the "god of heaven"). This set was called Serekh and Marie-Ange and Annie Bonhême Forgeau argues that would mean "to convey or proclaim". Probably the ability to fly very high and toward the sun could have caused this representation of Horus and the association with the monarch.

THE TWO LADIES (nbty) - This title would mean the two lands of Egypt. The South, Upper Egypt, would be identified by the vulture goddess Nekhabit and Delta (North), the snake goddess Wadjet or Uto, who is described after the vulture, a clear vision of the victory of the South over the North during the unification of Egypt.

HORUS OF GOLD or GOLDEN HAWK - This title appears to be associated with the myth of Osiris, the mythical struggle between Horus and Seth, and the solar cult, probably developed in the Old Kingdom during the primacy of Ra.

KING OF UPPER and LOWER EGYPT (nsw bity) - Accompanying the coronation name (name of the throne) of the monarch and be correlated with the solar cult. This title showed the duality of Egypt and the establishment of Pharaonic theocracy.

SON OF RA (sa-Ra) - This title accompanied the birth name of the monarch since the 5th dynasty. Indicated that the monarch was divine by birth and had sun character.

The first three royal titles could denote the characteristics of the dual nature of the monarch. The Horus of Gold is a good example. This was part of the Horus myth of Osiris, taking the deceased, in the funeral rite, in face of Osiris after the weighing of the heart. It also appears in the Ennead of Heliopolis having connection with the sun cult, thus assuming 
the divine and dual power of Ra and Osiris. On the other hand, this title was also identified with the monarch who assumed the throne of Egypt. The other two titles, crowning and birth (both probably the most important), could indicate the dual nature of the monarch, both with sun attributes: first, the institutional nature of Pharaonic theocracy, the other the divine nature of Pharaoh, once he was the "son of Ra."

This set of titles and epithets would ratify the divine character of the monarch and his action as ruler of Egypt. It could also represent, in general, a "government program". An example may clarify this issue.

When Akhenaten began his "revolution" was necessary to express it in your royal titles. Thus, the god Amon was replaced by the god Aten. Moreover, the best example of radical change would have been total replacement of his birth name of Amonhotep - "Amon is gracious" - to Akhenaten, which can be translated as "Soul of Aten", "Radiation of Aten", "He which is useful for Atum ". He also created a new epithet Uaen-Ra "The first of Ra." The full royal titles were the expression of materiality should be used in the public transcripts.

Apparently the Ptolemaic Dynasty also made use of magico-religious practices in the political-religious project to dynastic legitimacy. The strategy was to associate Greek epithets in the Egyptians royal titles. You can see some sophistication in the Ptolemaic royal titles during the reigns of Ptolemy IV and V. It seems these monarchs increased the adoption of practices related to Egyptian divine monarchy, possibly because of the rebellions in Egypt. Analysis of the Ptolemaic royal titles can contribute to the study of the dynastic legitimacy. We then use the technique of content analysis by André D. Robert and Annick Boulillaguet in the book L'Analyse de Contenu.

We used a simplified analysis frame to make clearer the application of the method based on four basic steps, namely: 1) A preliminary analysis aimed at defining a document corpus based on texts available, 2) the categorization distinguishing themes or thematic categories, which generally allow meaningful comparisons of the different text included in the corpus, 3) the boundaries of units that will determine the central points. Generally the units are classified as register of numbering or context, and finally 4) the qualitative analysis of content.

With these four central elements of the Analyse de Contenu was possible to create a simplified analytical framework that can be used for the analysis of texts and images. The numbering in the table reflects concisely the four steps of the method. Moreover, the analysis has been taken to 
two of the five possible royal titles, the coronation name / throne and birth name, most clearly seen in the texts, and in some ways, the most important in the magico-religious process.. In this article we take as an example only royal titles of Ptolemy $\mathrm{V}$ denoting apparently a closer relationship with Pharaonic culture, but also demonstrate significant innovations (epithets Greeks transcribed to the ancient Egyptian language and titles).

Table of Content Analysis: Royal titles of Ptolemy V

\begin{tabular}{|c|c|}
\hline \multicolumn{2}{|c|}{ Ptolomeu V Epifanes (210-204-180 a.C.) } \\
\hline \multirow{2}{*}{\multicolumn{2}{|c|}{$\begin{array}{l}\text { Bibliography (1) } \\
\text { Liddell and Scott's (1997), Holbl (2000), Gralha(2002), Chauvau (1997), www.narmer.pl }\end{array}$}} \\
\hline & \\
\hline \begin{tabular}{|l|l|} 
Texto(1) & Notes \\
\end{tabular} & Notes \\
\hline $\begin{array}{l}\text { the coronation name / } \\
\text { throne and birth name }\end{array}$ & $\begin{array}{l}\text { Partial analysis of royal titles: Ptolemy V Epiphanes's coronation } \\
\text { name / throne and birth name. }\end{array}$ \\
\hline \multicolumn{2}{|c|}{ Thematic Category (2): Divine Legitimacy } \\
\hline $\begin{array}{l}\text { Unity of register (3) } \\
\text { the coronation name/throne } \\
\text { King of Upper and Lower } \\
\text { Egypt. }\end{array}$ & Qualitative analysis of the content (4) \\
\hline 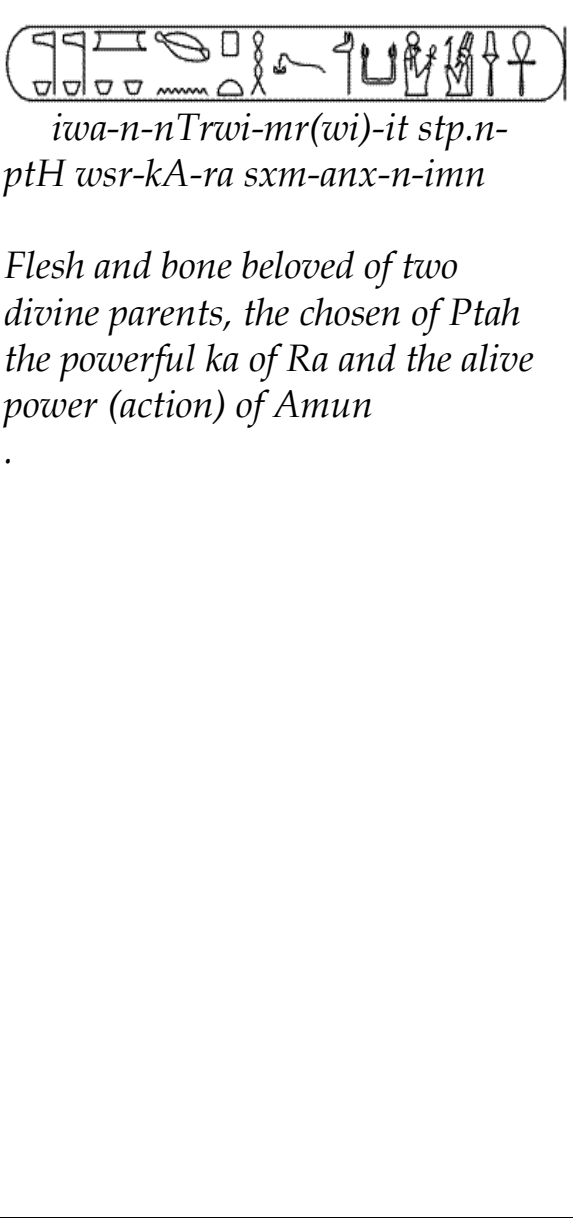 & $\begin{array}{l}\text { The term flesh and bones } \\
\text { as heir. A kind of epithet that represents an } \\
\text { innovation in royal titles. } \\
\text { the beloved of two divine parents } \\
\text { The correct designation to divine parents should be } \\
\text { The epithet represents an innovation and has } \\
\text { relationship to Ptolomeu V's parents (Ptolomeu IV } \\
\text { and Arsinoe III). It also represents the Greek epithet } \\
\text { Filopator in Egyptian hieroglyph. } \\
\text { Ptah, Amun Ra and composed the name of coronation } \\
\text { as divine legitimacy following the policy of his father. } \\
\text { The chosen of Ptah in the name of crown / throne } \\
\text { denotes a link to the Priests of Memphis. } \\
\text { the powerful ka of Ra } \\
\text { The monarch is the chosen of Ra as form of legitimacy } \\
\text { through god Ra, the sun god of Heliopolis in Lower } \\
\text { Egypt (north). }\end{array}$ \\
\hline
\end{tabular}




\begin{tabular}{|l|l|}
\hline $\begin{array}{l}\text { the alive power (action) of Amun } \\
\text { The monarch has the power of Amun (of action) in the } \\
\text { life which shows to be the power of god Amun } \\
\text { incarnate. An attempt to legitimacy through the god } \\
\text { of Thebes - the capital of Upper Egypt. }\end{array}$ \\
\hline
\end{tabular}

\begin{tabular}{|l|l|}
\hline $\begin{array}{l}\text { Unity of register (3) } \\
\text { birth name - son of Ra }\end{array}$ & \begin{tabular}{l} 
Qualitative analysis of the content (4) \\
\hline $\begin{array}{l}\text { Ptolemy living forever, beloved of } \\
\text { Ptah }\end{array}$
\end{tabular} \\
\hline $\begin{array}{l}\text { Unity of register (3) } \\
\text { Greek Epithet }\end{array}$ & $\begin{array}{l}\text { The birth name was transcript to Egyptian language } \\
\text { and has connection with the god Ptah showing a } \\
\text { strong approach to the priestly group of Memphis. }\end{array}$ \\
\hline $\begin{array}{l}\text { Epifanes } \\
\text { Qualitative analysis of the content (4) }\end{array}$ & $\begin{array}{l}\text { Manifestation, epiphany. (LIDDELL AND SCOTT } \\
\text { 1997, 264) } \\
\text { The epithet demonstrates the divine attribute of the } \\
\text { new monarch. He is divine by b Greek and the epithet } \\
\text { Pharaonic royal titles. } \\
\text { Ptolemy V shows the divine legitimacy in face of } \\
\text { Egyptian society and the pharaohs of Upper Egypt } \\
\text { during Theban Rebellion (206-186BC) }\end{array}$ \\
\hline
\end{tabular}

\section{Final considerations}

In this article, which is part of the master's and doctoral studies, our intention was to demonstrate that the Ptolemaic dynasty, in order to legitimize itself for almost three centuries, had to adopt pharaonic magical-religious practices. Thus, in a concise way, we approach four possibilities: legitimacy by means of deification, city building, temple building, and titles.

Significant element in this process refers to the Egyptianization of the Ptolemaic dynasty which may have been much more important for the maintenance and legitimacy of power relations than the Hellenization proposed by historiography.

Thinking Egypt from this period as a "Hellenized Egypt" only can mean a reduction of analysis in function of the complexity of this moment and may not elucidate the strategies and practices adopted by the monarchs 
of this dynasty. Moreover, historiography usually puts the Ptolemaic dynasty as something apart. It should be noted that these kings performed pharaonic rites, they were born on Egyptian land, adopted in part the Egyptian culture and ruled Egypt "in Egypt itself." That is, they are Pharaohs and not only Ptolemaic kings.

\section{Bibliography}

AUSTIN, M. The Hellenistic World from Alexander to the Roman Conquest: A Selection of Ancient Sources in Translation. Cambridge: Cambridge University Press, 1981.

COPPENS, Fillip. The Wabet: Tradition and Innovation in Temples of the Ptolemaic and Roman Period. Praga: Czech Institute of Egyptology, 2008.

BAGNALL, R \& DEROW, Peter. The Hellenistic Period: Historical Sources in Translation. Nova York, Blackwell Publishing, 2004.

BELL, Lanny. The New Kingdom "Divine" Temple: The example of Luxor. In: SHAFER, Byron E. (Editor). Temples In Ancient Egypt. New York: Cornell University Press. 1999.

BHABHA, Homi K. O Local da Cultura. Belo Horizonte: Editora UFMG, 2003.

BOWNMAN, Alan K. Egypt after the Pharaohs 332BC-AD642. London: British Museum Publications, 1986.

DUNAND, Françoise. Diex et Hommes en Egypte. 3000 av. J.C. - 395 apr. J.C. Paris: Armand Colin, 1991, pp 214-216.

FLANNERY, Kent V and MARCUS, Joyce. Cognitive Archaeology. In: HODDER, Ian and

FRANKFURTER, David. Religion in Roman Egypt: Assimilation and Resistance. Princenton: Princenton University Press, 1998.

FUNARI, Pedro P, ZARANKIN, A. Algunas consideraciones arqueológicas sobre a vivienda doméstica en Pompeya. Gerion, Buenos Aires, No 19 pp. 493-511, 2001.

FUNARI, Pedro P., HALL, Martin, JONES, Siân. Historical Archaeology. Back from the edge. London: Routledge, 1999. 
GOHARY, Jocelyn. Akhenaten's Sed-Festival at Karnak. London: Kegan Paul International. 1992.

GRALHA, Julio. Deuses, Faraós e o Poder. Rio de Janeiro: Barroso, 2002.

A Cultura Material do Cotidiano: Espaço Urbano e Moradias no Egito Faraônico. In: Funari, P.P.A.; Fogolari, E. P. (eds.) Estudos de Arqueologia Histórica. 1 ed. Habitus, Erichin (RS), pp. 115-132, 2005.

Arquitetura e iconografia templária: abordagem possível das práticas culturais e da legitimidade do poder no Egito Greco-Romano, Curitiba: 2005, vol 6, 49-68.

Power and Solar Cult in Ancient Egypt: An Iconographic and Politic-Religious approach. In: Funari, P.P.A.; Garraffoni, R. S.; Letalien, B. (eds). New perspectives on the Ancient World. Oxford: Archaeopress, 2008, pp. 167-174.

A Legitimidade do Poder no Egito Ptolomaico: cultura material e práticas mágico-religiosas, Campinas (Brasil). UNICAMP, 2009.

GRIMAL, Nicolas. A History of Ancient Egypt. Oxford: Blackwell, 1997.

HAENY, Gehard. A Short Architectural History of Philae. In: BIFAO. CAIRO: IFAO, volume 85, 1985, pp. 197-233.

HEINEN, H. The Syrian-Egyptian Wars and the new kingdom in Asia Minor. In: WALBANK. F. W. Cambride Ancient History - Hellenistic World. Cambridge: Cambridge University Press, 1984.

HOBL, Gunther. A History of the Ptolemanic Empire. London: Routledge, 2001.

HORNUNG, Erik. Conceptions of God in Ancient Egypt. The One and the Many. Ithaca (NY): Cornell University Press, 1996.

HORNUNG, Erik. Akhenaten and the Religion of Light. New York: Cornell University Press, 1999.

HUSSON, Geneviève \& VALBELLE, Dominique. L'État et les Institutions en Égypte des premiers pharaons aux empereurs romains. Paris: Armand Colin, 1992.

JOHNSON, Janet. The Demotic Chronicle as a statement of Theory of Kingship. The SSEA Jornual. Toronto, Canada, vol XIII, No 2, spring 1983 
. The Demotic Chronicle as Historical Source. ENCHORIA, Zeitschrift Fur Demostistik und Kptologie, IV, 1974.

JOUGUET. Pierre. La Politique intérieure du premier Ptolémée. in: BIFAO. CAIRO: IFAO, volume 30, 1930, p. 513-536.

KITCHEN, K. A. Pharaoh Triumphant The Life and Times of Ramesses II. Wiltshire: Aris \& Phillips LTD., 1982.

LEWIS, Naphtali. Greeks in Ptolemaic Egypt.Oakville-Connecticut: American Society of Papyrologists, 2001 (1986 1 ${ }^{\mathrm{a}}$ ed.).

. Life under Roman Rule. Oxford:Claredon Press, 1985.

LOBIANCO, Luís E. A Romanização no Egito: Direito e Religião (séculos I à III d.C.). Niteroi:UFF, 2006.

MESKELL, Lynn. Archaeologies of Social Life. Oxford: Blackwell, 1999

W.M. Müller, Egyptological Researches III. The bilingual decrees of Philae (Washington 1920), pp. 59-88.

MORENZ, Siegfried. Egyptian Religion. New York: Cornell University Press, 1996.

PINCH, Geraldine. Magic in Ancient Egypt. Austin: Universidade do Texas, 1994

P.W. Pestman, J. Quaegebeur, R. L. Vos, Recueil de textes démotiques et bilingues (Leiden: 1977): 11.

QUIRKE, Stephen. Ancient Egyptian Religion. London: British Museum Press, 1994.

Thames \& Hudson, 2001.

. The Cult of Ra. Sun-worship in Ancient Egypt. London:

ROBINS, Gay. The Art of Ancient Egypt. Cambridge (Massachusetts): Harvard University Press 1997.

- Women In Acient Egypt. Cambrige (Massachusetts): Harvard University. Press, 1993.

ROBERTSON D. S. Arquitetura Grega e Romana. São Paulo: Martins Fontes, 1997. 
SAUNERON, S. The Priests of Ancient Egypt. Ithaca: Cornell University press, 2000.

SADEK, Ashraf Iskander. Popular religion in Egypt during the New Kingdom. Hildesheim:Gersten-berg Verlag, 1987.

SCOTT, James C. Domination and the Art of Resistance: Hidden Transcripts. New Haven: Yale University, 1999.

SHAFER, Byron E. (Editor). Temples In Ancient Egypt. New York: Cornell University Press, 1999.

- (Editor). Religion in Ancient Egypt. Gods, Myths, and Personal Practice. New York: Cornell University Press, 1999.

SILVERMAN, David P. Divinity and Deities in Ancient Egypt, in Religion, in Ancient Egypt. SHAFER, Byron (Editor), London: Cornoell University Press, 1991.

TRIGGER, Bruce G. Early Civilizations. Ancient Egypt in Context. Cairo: The American University in Cairo Press, 1996.

VALBELLE, Dominique. Histoire de l'État pharaonique. Paris: Presses Universitaire de France, 1998.

WATTERSON, Barbara. The House of Horus at Edfu. Ritual in an Ancient Egyptian Temple. Great Britain: Tempus, 1998

WILKINSON, Richard H. The Complete Temples of Ancient Egypt .London: Thames \& Hudson, 2000.

Reading Egyptian Art : A Hieroglyphic Guide to Ancient Egyptian Painting and Sculpture.London: Thames \& Hudson, 1996.

WHINTER, Frederick. Studies in Hellenistic architecture .Toronto: Toronto University Press, 2006. 